\title{
Eighteenth-Century Orientalism in Contemporary British Historiography and Literary Criticism
}

\author{
Claire Gallien ${ }^{1 *}$ and Olivera Jokic ${ }^{2}$ \\ ${ }^{1}$ University Paul Valéry Montpellier (UPVM) \\ ${ }^{2}$ City University of New York (CUNY)
}

\section{Abstract}

To speak about orientalism now is to explain the persistent concern, among academic and non-academic readers and writers alike, with the transformative effect of Edward Said's Orientalism (1978). Said's text has been taken as a challenge by historians of society and of literature alike. To these scholars, the book offered a vast new field of inquiry into the relationship between European and colonial history, between cultural production and capitalism, and between Enlightenment idealism and the politics of domination. Orientalism was also a particular model of interpretive methodology, which repurposed Orientalism, once a term for cultural appreciation and interest, to name a relationship of mistrust, abuse, and control.

We show in this essay that Said's argument about the inextricable ties between Europe and its colonial domains has been so deeply absorbed as an intellectual, ethical, and political imperative that no serious scholarship is now imaginable that remains unaware of imperialism as a formative element of European history and culture. As a model of interpretive methodology, Said's work has been subjected to some of the most poignant and compelling criticisms, especially by contemporary British historiography and literary criticism working on the eighteenth-century period and whose purpose and effect have been to expand and improve the examination and understanding of imperialism and the enduring practices and implications of imperial culture.

What has perplexed eighteenth-century scholars and then encouraged them to take up the question of Orientalism was the fact that Said largely omitted periods prior to Bonaparte's expedition in Egypt in 1798 and provided a monolithic and hegemonic version of Orientalism as discursive formation, transportable and translatable to any given time and place. Scholars of the eighteenth-century period, and more particularly, given the scope of Said's research, those working in the fields of the history of empire and in literary criticism, have been keen to respond to the Orientalist challenge. This allowed them not only to embrace the Saidian perspective and revisit the corpus of eighteenth-century literature through the Orientalist prism but also, at a second stage perhaps, to refine and adapt the concept of Orientalism to time and place specifics and display a more anxious history of empire.

The re-reading of European textual materials with an eye to Orientalism has been (and continues to be) enabling of historicist understandings of literary representation and its potentially collusive relationship with the histories of colonialism. Developments in colonial historiography and related fields such as historical anthropology have made possible new insights into the relationship between eighteenthcentury English literature and empire. Orientalism also provided an analytical frame to think about matters related to the construction of tropes, the transformation of Eastern texts as they traveled across countries and continents, the promotion and demotion of genres, the question of canon formation, the birth of the "English" novel, gender, and the impact of other forces than empire, such as the book market, in determining Orientalist fashions.

To speak about orientalism now is to explain the persistent concern, among academic and nonacademic readers and writers, with the transformative effect of Edward Said's Orientalism. The text has become a challenge for historians of society and historians of literature alike because 
it proposed a vast new field of inquiry into the relationship between European and colonial history, between cultural production and capitalism, and between Enlightenment liberalism and the politics of domination. The ground for Said's book was prepared by Raymond Schwab's Oriental Renaissance, which had read in eighteenth-century Orientalism a new relationship between knowledge and creativity with "the power of regenerating European cultural and intellectual life between 1770 and 1870," especially in France and Germany. The transformation was generated by "the Different" received from Indian texts (and Sanskrit scholarship in particular), mitigating the exhaustion of Europe's own classical sources in the late eighteenth century and created the conditions for the emergence of European Romanticism.

Historian P. J. Marshall points out that by the time Schwab's text appeared in English translation in 1984, with Said's Introduction, "the historical record of the circumstances" in which these "discoveries were made" had been significantly altered by the attention of American, British, and Indian scholars to the relationship of Orientalist scholars such as Sir William Jones to the colonial project and to the relationship between the study of languages and eighteenth-century scholars' theological interests (317). At a historical and political remove from the optimism of Schwab's interpretation, Said's Orientalism repurposed its titular term: it treated Orientalism as a discourse emerging in conjunction with Napoleon's military campaigns to provide "the enormously systematic discipline by which European culture was able to manage - and even produce - the Orient politically, sociologically, militarily, ideologically, scientifically, and imaginatively" (3). Hardly "an innocent scholarly endeavor" (Said 333), a fashionable style of representation, or a source of cultural vitality, Orientalism became the name for one strategy of political and cultural domination by European powers over their colonial domains, an index of the disparities in power and access to knowledge production between the Europeans and those they ruled.

The effect of Said's claims and methodologies of interpretation has been a subject of great contention, political and intellectual, driven by the ambiguity surrounding the status of Orientalism as an analytic concept and a name for historical and political relationships and processes. Despite relentless and trenchant criticism, the central argument about the inextricable ties between Europe and its colonial domains has been so deeply absorbed as an intellectual, ethical, and political imperative that no serious scholarship is now imaginable that remains unaware of imperialism as a formative element of European history and culture. Seen as a precursor to "postcolonial theory," Said's work has had a deeply corrosive effect on imperial historiography and tone of discussions of the European presence in the proverbial "Orient." Orientalism's argument regenerated the study of "other regions of what has been defined as the 'Orient' " (Breckenridge and van der Veer 3), drawing attention to the significance of Orientalist discourse as a way of understanding any region that made up the geography of European political and economic interests. Attention to the ambivalence at the center of European culture about the proximity of the history of intellectual and artistic achievement to the history of imperialism has reshaped all disciplines concerned with textual and visual interpretation and with regions outside Western Europe.

Some of the most poignant and compelling criticisms questioned Orientalism's bona fides as a model of interpretive methodology whose purpose and effect have been to expand and improve the examination and understanding of imperialism and the enduring practices and implications of imperial culture. On the assumption that all previous historiography had been a genre of Orientalist writing, Said's Orientalism could be "an argument for an antifoundational History" (Prakash Perspectives 398), from which it was possible to "articulate a post-Orientalist interpretive position that would trace third-world identities as relational rather than essential" (Prakash Perspectives 399). Such emphasis on the ideological work of discourses in their production of subjects and subjectivities called for an interrogation of the conditions on which 
certain models of representation became venues of historical realism and of social and cultural historiography. Enabling of a new critical position placing colonialism at the center of European history, Said's proposition that Orientalism was "a style of thought based upon an ontological and epistemological distinction made between 'the Orient' and (most of the time) 'the Occident' " (3) was met with resistance from those who found this to be a rigid and unsophisticated framework of interpretation, an inaccurate and politically unproductive deterrent to proper historiography or ethnography. As recently as 2006, Robert Irwin argued that Said's work created sets of oppositional historical figures that have rendered invisibly a particular intellectual climate in which "Orientalism was and is a subset of Western scholarship in general" and "a special case study of the role of academics in cultural life." (3) The argument that Orientalism was "the hegemonic discourse of imperialism" created a pervasive "distortion" against which it became impossible to "reflect rationally and dispassionately about the subject" (4) and write the "true history of Orientalism." (5)

Noting that what Said had offered in Orientalism as a "provocation and an intervention, a beginning" could "become an ending, something so proven that it requires little further effort" (Makdisi Romantic Imperialism $226 \mathrm{n} 6$ ); interventions concerned with providing more refined historical accounts of colonialism and its consequences have focused on the ways in which a "better" historiography remains beholden to concepts that Orientalism had set out to undo or overcome. To examine whether Orientalism was a product or a condition of the colonial relationship, scholars have focused on the relationship between discourses and governmental practices that made up the social and historical processes of colonization. As a mode of reference or a model of representation, was it possible, especially in the eighteenth century, prior to the consolidation of European empires, that not all Orientalism was used for the suppression and domination of the native populations, because

orientalism was not directed solely at the construction of ruling authority upon European terms, but rather, was also a series of strategies to coopt, control and adapt elements of established Indian social, cultural, and political authority? (Dodson 5)

Lisa Lowe has suggested in her study of "French and British Orientalisms" that it is important to think of Orientalism emphatically as a discursive formation because this is how it is prevented from becoming an "ontology of Occident and Orient [which] appears in a consistent manner throughout all cultural and historical moments" (5). Such a study dismantles the imagined binary opposition, which occludes the variety of meanings attributed not only to the location and size of the "Orient" in different historical periods and within different national cultures but also to the shifting "notions such as 'French culture,' 'the British Empire,' and 'European nations.' " (7) Lowe insists that representations of the Orient have not always or exclusively been expressions of a colonial relationship and that Orientalism has been "bound up with" alternative discursive forces, such as medical and anthropological classifications of race, psychoanalytic versions of sexuality, and capitalist and Marxist constructions of class. These discourses could "reanimate" or accommodate Orientalism, and attention to this volatility can be a way to "destabilize the power of orientalism" (10) as a monolithic, implacable, reductive, and extractive system of representation and governance. Going against a hegemonic understanding of Orientalism, Kate Teltscher's India Inscribed suggests that eighteenth-century representations of India (in parliamentary debates, histories, travel accounts, and missionary letters, as well as novels, poetry, and illustrations) need not be read as manifestations of colonial power but rather as moments of unsettled cultural confidence.

The degree to which any discourses or disciplines of representation can be extricated from the colonial project has been a crucial question about what it is that Orientalism names or represents. 
The question of relationship between the "discourse of Orientalism" and Orientalism as government policy has been inextricable from the tectonic shift in the scholarship about the eighteenth century, from arguments about a long period of calm and peaceful change toward a "new eighteenth century" that was also a "global eighteenth century" (Felicity Nussbaum) giving the vital impetus to a "new imperial history" seeking to accommodate views from colonies, or even from points of view reluctant to take a geographical position - for example, the transatlantic or that operating across the Indian Ocean. Renewed attention to historical archives, documentation, and interpretation has produced a revised timeline of watershed moments in the history of European imperialism, such as the impeachment trial of the East India Company GovernorGeneral in India Warren Hastings. The charges drafted by Edmund Burke "represent the first exhaustive compilation of colonial guilt to emerge from the colonization of India," and new accounts of colonial history emphasized the ambivalence of colonial relationships, because "the exercise of 'arbitrary power' for which [Burke] sought to impeach Hastings could not be so easily expunged from the history of colonization" (Suleri 51). The trial brought "the corruption, venality, and duplicity of the British presence in India to the attention of the world," and when Hastings was acquitted, the failure of Burke's "reformist agenda...ironically made Empire seem a natural extension of British sovereign and commercial rights and interests" (Dirks Scandal xii).

Attention to the historical links between disciplinary discourses and colonialism has been explicitly named as the crucial task for scholars attending to the "postcolonial predicament," that is, the persistence of colonialist discourse in the possibilities of knowledge about the former colonial domains, tied to the "role of...academic disciplines in the reproduction of patterns of domination" (Breckenridge and van der Veer 1), from anthropology (Lowe 23 fn22), to English literature (Viswanathan), and to comparative literature (Ahmed Babel 296). Lata Mani and Ruth Frankenberg assume, with Said, the "complicity between Orientalism and imperialism" in the eighteenth and nineteenth centuries, from which emerges "an authoritative body of knowledge about Asia and parts of Africa" (177), in order to explain how Orientalism's "attachment to institutional power has enabled its remarkable, continued and widespread persistence" (178). Precisely, because it was a part of an institutional effort and policy, Orientalism has been a flexible instrument of power, allied with discourses such as "literature" and law in the eighteenth century and later with modern technologies of rule, such as surveys, statistics, governance, and population control. Tony Ballantyne explains, for example, that the appreciative aspects of the eighteenth-century Orientalists' genuine and intense interests in the "native" populations and their cultural production had the effect of

render[ing] the places of interest static, unchanged and unchangeable in history, given a 'tradition' and a set of 'customs' and the lack of ability to live with modernity as a dynamic set of practices. (Ballantyne Modernities 25).

The emphasis on the volatility and historicity of Orientalist discourse has softened the dichotomies of colonial encounter, making room for new scenes and accounts of the distribution of agency that countered the implication in Said's work "that colonial power and discourse is possessed entirely by the colonizer, which is a historical and theoretical simplification." (Bhabha Question 25) Any historiography of colonialism now contending with the methodological and ideological questions regarding the representation of indigenous populations, their agency, or resistance in the colonial encounter may be said to be both an heir to and a critic of the work of Orientalism (e.g., Tony Ballantyne, Antoinette Burton, Nicholas Dirks, Bhavani Raman, Ann Laura Stoler, Thomas Trautmann, Phillip Wagoner, Kathleen Wilson, Betty Joseph, and Mohamed Tavakoli-Targhi). Because of the ambivalence at the heart of the colonial project and ideology, scholars such as Tony Ballantyne, following Jane Burbank 
and Frederick Cooper, suggest that the most productive understanding of empire may not be in terms of fixed identities it produced but with regard to imperial power as it emerged within the relationships between empires and between the colonizers and the colonized (Ballantyne Orientalism 5).

Mohamad Tavakoli-Targhi's Refashioning Iran: Orientalism, Occidentalism, and Historiography, for instance, is an attempt at "decolonizing historical imagination" that acknowledges indigenous contributions to the production of colonial and orientalist knowledge. It treats the "double consciousness" whereby Persians "critiqued European social settings with their own ethical standards and censured their own society from a European perspective" (53) as a critique of forgetting (including Said's own) of the Persian challenges to nineteenth-century and twentieth-century discourses about the supremacy and self-sufficiency of European rationalism and Enlightenment. Ahmad Gunny investigates in Images of Islam in Eighteenth-Century Writings the representations of Islam and Muslims in eighteenth-century Europe (particularly France) in the context of the genealogy and reinforcement through variations of Western cultural prejudices against Islam dating back to the Crusades. Gunny restricts his enquiry to non-fiction, assuming that fiction would be too fanciful to reflect the "Enlightened" view of Islam he intended to illustrate. Gunny paved the way for the more recent revisionist scholarship focusing on the multifaceted responses of Enlightenment thinkers to Islam, the Quranic texts, the Prophet Muhammad, and Muslim empires and populations. Challenging the Saidian view of a monolithic, agonistic, and dismissive treatment of Islam, critics such as Mohammed Sharafuddin in Islam and Romantic Orientalism, Ziad Elmarsafy in The Enlightenment Qur'an, and Humberto Garcia in Islam and the English Enlightenment, 1670-1840, showed how these images were shaped by political, religious, and nationalist agendas of authors who gave Islam a central position in the Enlightenment project. Garcia argues, for instance, that Islamic Republicanism was a key reference in revolutionary France and America and read as a critique of English liberty.

These scholarly works have challenged the narratives underwriting Said's historiographical understanding of Orientalism as a secularist worldview, which displaced religious and theological discourses from Protestant England to an Eastern "religious" other. This critique is brilliantly elucidated in Eitan Bar-Yosef's The Holy Land in English Culture, 1799-1917, which shows how the pervasive impact of a late seventeenth-century and eighteenth-century biblical prophetic idiom to describe the Middle East renders ineffectual Said's notion of Orientalism as an explanatory historical model. In Imperial Babel: Translation, Exoticism, and the Long Nineteenth Century, Padma Rangarajan argues that the process of translating British and Indian texts transformed the identities of the colonizers and of the colonized, such that a colonial history of translation "compels a reconsideration of the history of orientalist studies and its relationship to nineteenth-century British culture" (ix). David Do Paço's L'Orient à Vienne studies the movements in eighteenth-century Europe of Ottoman merchants and diplomats whose access to the sources of legal and administrative power and to the "treasures" expected from the East challenged the privileges of local commercial and political elites in cities such as Vienna.

Recent scholarly and editorial work on Indian authors writing ethnographies of the West that contest Orientalist stereotypes similarly undermines Said's claim that Western textual power was "advancing 'securely and unmetaphorically upon the Orient' " (Leask Traveling 220). Daniel O'Quinn's edition of The Travels of Mirza Abu Taleb Khan and Nigel Leask's analysis of that text remind us of the work of an Indo-Persian poet and munshi (scribe) who traveled in Europe between 1799 and 1803, writing "as the representative of the late eighteenth-century Bengali intelligentsia" and offering a "comparative analysis of Asian and European cultures without subscribing to the historicist telos which would come to dominate the nineteenth-century colonial world" (Leask Traveling 223). The Travels of Sake Deen Mahomet (1793), edited by 
Michael H. Fisher, is an epistolary autobiographical narrative by a soldier in the British colonial army (and eventually an immigrant in Britain) reflecting on the effects of imperial expansion on the changing economic and political conditions facing local populations and waged laborers in the service of European companies chartered for trading "in the East."

These attempts to give agency to the colonized are, in a larger context, an effort to see colonization not as a totalizing process or force but one defined by - and challenging because of - its complicated relationship to Enlightenment ideologies of freedom, self-determination, and personhood. This attention to colonial ambivalence extends to Said's "love-hate relationship" to humanism (MacKenzie 130) as a political horizon that would countervail reductive representation. While Said has called for humanism as an effort "to use one's mind historically and rationally for the purposes of reflective understanding and genuine disclosure," "sustained by a sense of community with other interpreters and other societies and periods" (Orientalism xxiii), scholars have come to see this goal as counterproductive. In an effort to produce a range of new kinds of knowledge previously impossible or unrecognized, humanism itself has been recognized as an ambiguous product of eurocentric historiography, a political possibility "by which Western man fabricates his 'self' into a coherent identity, positing himself as beginning and end of all Knowledge and grandly naming it Humanism” (Bhatnagar 6).

Such expanded historical contexts have placed Orientalism and colonialism squarely in the midst of histories of capitalism, which cut across borders of nation states and require disregard for the correlate boundaries of national literatures or cultural identities. In the discussions of the relationship between imperialism and capitalism, Orientalism has been treated as a narrative instrument of differentiation, serving imperialism as a particular form of capitalism in which the expectation of pecuniary gain is justified by a cultural discourse of inferiority that can also posture as a form of appreciation. This double move makes it difficult to differentiate between the political and the aesthetic gesture and therefore difficult to produce a historical narrative that grants agency while also taking it away. In the words of historian Gyan Prakash,

If the configuration of class forces produced indigenous agents for India's colonization, why was it that these remained just that - collaborators? How did the universalistic logic of capital discriminate between turning power over to the English company and making the natives into the ruled? (Prakash 'Ride' 177)

The re-reading of European textual materials with an eye to Orientalism has been (and continues to be) enabling of historicist understandings of literary representation and its potentially collusive relationship with the histories of colonialism. Developments in colonial historiography and related fields such as historical anthropology have made possible new insights into the relationship between eighteenth-century English literature and empire. Rejecting the triumphalism of imperial historiography, which presented the British as heroic rescuers of a corrupted civilization and nationalist accounts of the British as aggressors and looters, revisionist historians have argued that in early British colonialism, corresponding roughly the second half of the eighteenth century, was not defined by confident territorial control over India but rather by careful strategic games cognizant of the local political and social traditions. Attention to colonialism as a process, rather than a static condition, has produced studies on the relationship between literary writing and empire within a particular set of ideological and historical circumstances. Amal Chatterjee argues in Representations of India, 1740-1840: The Creation of India in the Colonial Imagination that there was a transitional moment between mid-eighteenth-century representations, focusing on wealth and corruption entailed by the Indian experience, and discourses on religion, race, and progress, which preoccupied late eighteenth-century and early nineteenthcentury writers and paved the way for later Victorian imperial images of India. Other literary 
historians, such as Michael Franklin in Romantic Representations of British India, have explored the variety, complexity, and quality of responses between 1780 and 1850 to the "synchronous growth of imperialism, Romanticism and Orientalism" (17). Emerging representations of the East as exotic, backward, and barbaric have been set in even larger theoretical frames in Tilottama Rajan's Under Western Eyes: India from Milton to Macaulay and Pramod Nayar's English Writing and India, 1600-1920: Colonizing Aesthetics.

Accounts of imperialism prior to consolidation have inspired critics to look at literature for traces of insecurity and anxiety about the viability of the British Empire. Nigel Leask explored this question in British Romantic Writers and the East: Anxieties of Empire, noting that Romantic studies had been slow in seeing the Romantic age through the lens of imperialism. Leask addresses this omission by exploring how the work of Byron, Shelley, De Quincey, and other Romantic writers registers the fears of corruption and degeneration implied in the imperialist project taking shape. Daniel O'Quinn addresses the same preoccupations in Staging Governance: Theatrical Imperialism in London, 1770-1800, studying plays long ignored because of their topicality and minor aesthetic value. O'Quinn elucidates the political significance of plays representing empire on the London stage as projections of metropolitan anxiety concerning the transfer of political, financial, and moral corruption from the colony to the metropolis. Complementing Sara Suleri's analysis of the Hastings trial in The Rhetoric of English India, O'Quinn unveils the Hamletian and Macbethian intertexts in the speeches delivered at the court and explores the different ways in which the empire was anxiously consumed at home. Javed Majeed's Ungoverned Imaginings had explored similar dissonances in colonial discourse by positioning Mill's radical and Utilitarian approach to India against the "ungoverned imaginings" of the poetry of Sir William Jones and Thomas Moore, which had served to establish a conservative and by then defunct system of government in India.

In order to explain the once-intense interest in what is often dismissed as "fiction" or a paraliterary (i.e., depoliticized) form of the "Oriental tale," scholars have addressed the significance of this genre beyond its putatively decorative, supplementary, or "minor aesthetic" value to the canonical catalogue of forms and motifs. Michael Franklin has made crucial contributions to the study of eighteenth-century orientalist fictions about India, relating the history of empire and of the world of late eighteenth-century orientalist scholarship in India to the percolation of orientalism into pseudo-orientalist stories, for example, in his authoritative edition of Phebe Gibbes' Hartly House Calcutta.

This scholarship suggests that the traffic in Oriental material was neither directional nor did it finish with the end of Orientalist fashion or British imperial consolidation in the early nineteenth century. Attending to the history of this process in the works of Wordsworth, Austen, Byron, and Dickens, Makdisi establishes a relationship between Romanticism and the empire, building on his argument in Romantic Imperialism about a significant shift underway during the Romantic period in the understanding of colonial spaces and populations. Prior to the rigidity of Orientalist condescension of Victorian empire, the deployment of Oriental materials in the Romantic period, and interest in the lives of those later to be governed, offered imaginative alternatives to later imperialist individualism and self-containment.

In an effort to disentangle literature from nationalist agendas and to disrupt the codependence between nationalism and the literary canon, scholars have emphasized the hybridization at work in the production of literary texts and suggested a revision of the history of the English novel by focusing on its ability to integrate elements from "Eastern" texts, forms, and genres. Chapters of Saree Makdisi's edition of The Arabian Nights in Historical Context discuss this process of cross pollination. Rebecca Carol Johnson, Richard Maxwell, and Katie Trumpener argue in "The Arabian Nights, Arab-European Literary Influence, and the Lineages of the Novel" that the influence of the "oriental tale" can be found at the center of British canonical writing, 
exemplified by the experimental narratives of Laurence Sterne. Giving "the Orient" and "the Oriental" a formative role in the emergence of canonical literary genres, these scholars suggest alternative histories of European canonical literature and of the relationship between Europe and Asia.

The work of Srinivas Aravamudan has been crucial in addressing the relationship between empire, nationalism, and literary form. In Enlightenment Orientalism and elsewhere, Aravamudan treats representations of "the Orient" and the genre of the "oriental tale" as tropes helpful for appreciating the importance of the non-European (and later colonial) understandings of Europe. To re-claim "the Orient" and "the Oriental" in this sense has been to re-claim an alternative history of canonical literature and with it a different historiography of the relationship between Europe and Asia. Tropicopolitans provides a compelling explanation for the way dilemmas between faithful and unfaithful representations remain a double bind whose goal is to avoid politicizing the "Orient" and the "Oriental" text. Aravamudan examines Orientalist tropes in a broad range of orientalist literature (Aphra Behn's Oroonoko, Daniel Defoe's Robinson Crusoe and Captain Singleton, Joseph Addison's Cato, Jonathan Swift's Gulliver's Travels and The Drapier's Letters, Samuel Johnson's Rasselas, William Beckford's Vathek, Lady Mary Montagu's travel letters, Olaudah Equiano's autobiography, Edmund Burke's political and aesthetic writings, and Abbé de Raynal's Histoire des deux Indes), not for what the texts reveal or conceal of the Eastern world but for their function as sites of anticolonial agency. Aravamudan's term "tropicopolitans" names "residents of the tropics subjected to the politics of colonial tropology, who correspondingly seize agency through contesting language, space, and the language of space that typifies justifications of colonialism" (6), who are "troublesome tropes that - and colonial subjects who-interrupt the monologue of nationalist literary history" (12).

Disrupting the dichotomy on which the neat paired notions of metropole and colony are constructed and using an approach that foregrounds mutual formative processes, Daniel E. White's From Little London to Little Bengal traces the traffic in cultural artifacts between Calcutta, described by some as Little London, and London, which became Little Bengal for the community of Indianized expatriates returning home. White's material and cultural history of the exchanges of books, ideas, and religious formations between East and West draws our attention to the mutual imbrication in the construction of metropolitan and colonial identities, arguing that definitions of cosmopolitan modernity were forged, supported, and challenged over transnational routes. Similarly, Saree Makdisi questions dichotomies between European selves and non-European others at the heart of Said's version of Orientalism in Making England Western (2014), focusing on the processes whereby particular sections of the English population, much like colonial subjects, were described as waiting to be Occidentalized and civilized.

This new field of enquiry is fundamental not only for scholars interested in questions related to representations of the East in eighteenth-century literature but also for scholars concerned with the extent and dynamics of eighteenth-century literary production and translation. Revisiting seldom-read texts in "minor" genres, they model a methodology of interpretation less invested in the common preconceptions about the form and the process of production of "good literature." For instance, Ros Ballaster provides a crucial reconsideration of oriental tales in eighteenth-century England in Fabulous Orients. Instead of organizing her study by genre, she considers three locations, the Persian and Ottoman seraglios, the Chinese court, and the treasures of India, each indicating a mode of interaction with the East. Much like Aravamudan, Ballaster treats these representations as performative rather than referential, focusing on the ways in which these "narratives moved" from East to West and by doing so, "moved" political, social, cultural, philosophical, and sexual boundaries in England.

Anthologies such as Robert Mack's Arabian Nights' Entertainments, Ros Ballaster's Fables of the East: Selected Tales 1662-1785, Mary Ellis Gibson's Anglophone Poetry in Colonial India, 
1780-1913, Rosinka Chaudhuri's definitive edition of the works of Henry Derozio, and Norbert Schürer's "Surveying the Eighteenth-Century Anglo-Indian Canon," bring to light a trove of texts that had been disregarded by scholars of eighteenth-century literature. Delving into this pseudo-oriental literary corpus, Claire Gallien examines in L'Orient anglais the interactions between "fanciful" fictions of the East and knowledge of the East as produced by seventeenth-century and eighteenth-century orientalists, thus calling into question the very separation of "ungoverned imaginings" (Javeed Majeed) on the one hand and regulated, scholastic erudition on the other.

Furthermore, re-situating "pseudo-Orientalist" literature within the rich context of its production and reception, scholarly work has emphasized how the commercial logic of England's eighteenth-century book market shaped literary canon and the place it designated for "the Oriental." Drawing on socioeconomic history and history of the book, Ashok Malhotra argues in Making British Indian Fictions 1772-1823 that "the demands and internal historical development of the novel, the verse, or the theatre, and the status of the various authors, affected the portrayals of India" (3). Instances of cultural change that affected the depiction of India were larger theater sizes, the growth of illegitimate theaters, and the development in visual technologies. Imaginary visions of India were enhanced not because of the strengthening of cultural prejudices but rather because stage productions were increasingly concerned with attracting large audiences to lavish spectacles. Paying attention to the changing internal demands of literary modes, Malhotra establishes distinctions among portrayals of India in novels, poetry, and plays and demonstrates how particular internal development of literary modes affected Orientalist depictions.

The relationship between Orientalism, capitalism, and Empire acquires a different hue in the work that examines how the expanding markets required the violence of colonialism and its aesthetic and ethical justifications. In The Stillbirth of Capital, Siraj Ahmed argues that modern readers overlook, misread, or ignore representations of the East by thinkers of the Enlightenment, a concept retrofitted to explain the period it purports to describe. Acknowledging Enlightenment's complicity with the imperial project, Ahmed contends that we should re-read Enlightenment texts as directly concerned with the question of empire and take into account Enlightenment writers' interrogation of the ambivalent origins of European modernity, as well as their criticism of the violence of imperialism. Foregoing Robinson Crusoe as the prototypical study of colonization, Ahmed examines how Defoe's Captain Singleton (1720) treats of the competing interests of piracy and privateering, of the individual interests of unruly seafarers, and of the process of empire building by global monopolies and commercial outfits chartered by national governments.

Establishing a close relationship between the political and the literary history of Orientalism has been crucial for the consideration of gender and gender representation in texts from and about "the East." Betty Joseph proposes in Reading the East India Company that a critique of colonialism "shot through with a feminist perspective" (3) provides a compelling alternative to conventional accounts of colonial encounter centered on the "representative man." The feminist perspective requires a re-conception of the notion of historical archive, and Joseph proposes a history of women's activity that examines "how women are put together as subjects and objects of various discourses for the ruses and deployments of colonial power" (4). Nandini Bhattacharya argues in Reading the Splendid Body that male authors projected onto Indian women or Indianized British women libidinal and consumerist desires. The same question of masculinity and the feminized Orient was addressed by Mita Choudhury in "Gazing at His Seraglio: Late Eighteenth-Century Women Playwrights as Orientalists." Critics have also been interested in the question of the feminine Orientalist gaze and the extent to which it differed from its male counterpart. Felicity Nussbaum's essay "British Women Write the East after 
1750: Revisiting a 'Feminine' Orient” and Rosemary Raza's In Their Own Words: British Women Writers and India 1740-1857 are two crucial contributions to this body of critical studies.

The wealth of approaches to the question of Orientalism in eighteenth-century literature has brought to the attention of scholars not only texts and genres that had been lost to the canon but also the many complex and difficult relationships between literary scholarship and other kinds of inquiry and interpretation. This is why the topic is hardly exhausted, and we may safely assume that one future perspective could be to think about the ways in which we want to address these texts both critically and pedagogically. This perspective is crucial if we are serious about effectively disrupting the close ties between nationalism and received notions of the canon. Diane Long Hoeveler and Jeffrey Cass trailed a path in Interrogating Orientalism (2005) for a reflection on pedagogical practices in relation to Orientalist texts. Their example is successfully followed by Norbert Schürer and Tim Keirn in British Encounters with India, 1750-1830: A Sourcebook, while the students and teachers of history have at their disposal Antoinette Burton's Empire in Question: Reading, Writing, and Teaching British Imperialism. These studies hardly exhaust the need for scholarship that addresses the connections and interactions among texts and reading markets of the eighteenth century, or between minor genres and texts and canonical works. Another area that remains relatively understudied concerns the connections among literary trends within Eastern and Western traditions in the eighteenth century. Further comparative and translation studies could be instrumental in drawing up a specific map of literary encounters that would explicate the modalities of transfer of Eastern texts into the fictions in English.

This essay has looked into the state of the fields of eighteenth-century history and literature as regards the question of Orientalism since the publication of Said's book and examined the ways in which scholars of both disciplines dealt with the topic. Given the scope of this article, we indicated in the bibliography a comprehensive list of articles published in Literature Compass on related matters, which we could only succinctly address. These include the Far East, the Americas and Africa, blackness and slavery, postcolonial Enlightenment, The Arabian Nights, and orientalist scholarship.

\section{Short Biographies}

Claire Gallien is Associate Professor of English at Montpellier 3 University. She teaches in British literature and history, and her research focuses on seventh-century and eighteenthcentury orientalism and on contemporary Arab literature in English. Her research interests relate more broadly to postcolonial, comparative, and global literatures and theories.

Olivera Jokic is Associate Professor of English at John Jay College of the City University of New York. She teaches and writes on eighteenth-century and nineteenth-century British literature, on the relationship between writing and colonialism, and on gender.

Note

* Correspondence: English, Montpellier 3 University, Montpellier 34000, France. Email: claire.gallien@gmail.com

\section{Works Cited}

Ahmed, Siraj. 'Notes from Babel: Toward a Colonial History of Comparative Literature.' Critical Inquiry 39.2 (2013): 296-326. CrossRef. Web. 6 Oct. 2014.

—. The Stillbirth of Capital. Enlightenment Writing and Colonial India. Stanford, CA: Stanford University Press, 2012.

Aravamudan, Srinivas. 'Fiction/Translation/Transnation.' A Companion to the Eighteenth-Century English Novel and Culture. Eds. Paula Backscheider and Catherine Ingrassia. Oxford: Blackwell, 2005. 48-74. 
—. 'In the Wake of the Novel: The Oriental Tale as National Allegory.' Novel: A Forum on Fiction I.33 (1999): 5-31.

—. Tropicopolitans: Colonialism and Agency, 1688-1804. Durham, NC: Duke University Press, 1999.

- Enlightenment Orientalism: Resisting the Rise of the Novel. University of Chicago Press, 2011.

Ballantyne, Tony. 'Empires, Modernisation and Modernities.' International Journal for History, Culture and Modernity 2.1 (2014): 25-42. IngentaConnect. Web.

- Orientalism and Race: Aryanism in the British Empire. Palgrave Macmillan, 2002.

Ballaster, Ros. Fabulous Orients. Fictions of the East in England, 1662-1785. Oxford: OUP, 2005.

Bar-Yosef, Eitan. The Holy Land in English Culture 1799-1917 : Palestine and the Question of Orientalism. Oxford: Clarendon Press, 2005.

Bhabha, Homi. The Location of Culture. London and New York: Routledge, 1994.

Bhatnagar, Rashmi. 'Uses and Limits of Foucault: A Study of the Theme of Origins in Edward Said's "Orientalism." ' Social Scientist 14.7 (1986): 3. CrossRef. Web. 4 Oct. 2014.

Bhattacharya, Nandini. Reading the Splendid Body: Gender and Consumerism in Eighteenth-Century British Writing on India. Newark [N.J.]: University of Delaware Press, 1998.

Breckenridge, Carol A. and Peter van der Veer. Orientalism and the Postcolonial Predicament: Perspectives on South Asia. University of Pennsylvania Press, 1993.

Burbank, Jane and Frederick Cooper. Empires in World History: Power and the Politics of Difference. Princeton University Press, 2010 .

Burton, Antoinette. After the Imperial Turn: Thinking with and Through the Nation. Duke University Press, 2003.

- Empire in Question: Reading, Writing, and Teaching British Imperialism. Duke University Press, 2011.

Chatterjee, Amal. Representations of India, 1740-1840: The Creation of India in the Colonial Imagination. Basingstoke: Macmillan, 1998.

Derozio, Henry. Derozio, Poet of India : The Definitive Edition. Ed. Rosinka Chaudhuri. New Delhi: Oxford University Press, 2008.

Dirks, Nicholas B. The Scandal of Empire. India and the Creation of Imperial Britain. Cambridge, MA: Harvard UP, 2006.

Dodson, Michael S. Orientalism, Empire and National Culture. New Delhi: Foundation Books, 2010.

Do Paço, David. L'Orient à Vienne au dix-huitième siècle. Oxford: Oxford University Studies in the Enlightenment, 2015.

Elmarsafy, Ziad. The Enlightenment Qur an: The Politics of Translation and the Construction of Islam. Oxford: Oneworld, 2009. Franklin, Michael J. Romantic Representations of British India. London: Routledge, 2006.

—. "The Hastings Circle": Writers and Writing in Calcutta in the Last Quarter of the Eighteenth Century.' Authorship, Commerce and the Public: Scenes of Writing, 1750-1850. Eds. Caroline Franklin et al. Basingstoke: Palgrave, 2002. 186-202. Gallien, Claire. L'Orient Anglais. Connaissances et Fictions Au XVIIIe Siècle. Oxford: SVEC, 2011.

Garcia, Humberto. Islam and the English Enlightenment, 1670-1840. Baltimore: Johns Hopkins University Press, 2012.

Irwin, Robert. For Lust of Knowing : The Orientalists and Their Enemies. London: Allen Lane, 2006.

Johnson, Rebecca Carol, Richard Maxwell, and Katie Trumpener. 'The Arabian Nights, Arab-European Literary Influence, and the Lineages of the Novel.' Modern Language Quarterly 68.2 (2007): 243-279.

Joseph, Betty. Reading the East India Company, 1720-1840: Colonial Currencies of Gender. Chicago: University of Chicago Press, 2004.

Leask, Nigel. British Romantic Writers and the East: Anxieties of Empire. Cambridge: CUP, 2004.

- Curiosity and the Aesthetics of Travel Writing, 1770-1840: "From an Antique Land." Oxford: OUP, 2002.

Lowe, Lisa. Critical Terrains: French and British Orientalisms. Ithaca: Cornell University Press, 1994.

Mackenzie, John M. 'Edward Said and the Historians.' Nineteenth-Century Contexts 18.1 (1994): 9-25. Taylor and Francis+NEJM. Web. 6 Oct. 2014.

Majeed, Javed. 'Chapter 1. Sir William Jones.' Ungoverned Imaginings. James Mill's the History of British India and Orientalism. Oxford: Clarendon Press, 1992.

Makdisi, Saree. Making England Western: Occidentalism, Race, and Imperial Culture. Chicago: The University of Chicago Press, 2014.

- Romantic Imperialism: Universal Empire and the Culture of Modernity. Cambridge, United Kingdom; New York: Cambridge University Press, 1998.

Makdisi, Saree and Felicity Nussbaum. The Arabian Nights in Historical Context: Between East and West. Oxford; New York: Oxford University Press, 2008. Print.

Malhotra, Ashok. 'Book-History Approaches to India: Representations of the Subcontinent in the Novel and Verse, 1780-1823.' History Compass 8.2 (2010): 143-151.

Malhotra, Ashok. Making British Indian Fictions, 1772-1823. London: Palgrave Macmillan, 2012.

Mani, Lata and Ruth Frankenberg. 'The Challenge of Orientalism.' Economy and Society 14.2 (1985), 174-192.

Marshall, P. J. 'Empire and Authority in the Eighteenth Century.' Journal of Imperial and Commonwealth History 15 (1987): 105-22.

Nayar, Pramod K. English Writing and India, 1600-1920: Colonizing Aesthetics. London: Routledge, 2008. 
Nussbaum, Felicity A. 'Between "Oriental” and "Blacks so Called,” 1688-1788.' The Postcolonial Enlightenment: EighteenthCentury Colonialism and Postcolonial Theory. Ed. Daniel Carey and Lynn Mary Festa. Oxford: Oxford University Press, 2009. 137-166.

—. 'Slavery, Blackness, and Islam: The Arabian Nights in the Eighteenth Century.' Slavery and the Cultures of Abolition: Essays Marking the Bicentennial of the British Abolition Act of 1807. Ed. Brycchan Carey and Peter J. Kitson. Woodbridge: D.S. Brewer, 2007. 150-172.

- The Global Eighteenth Century. Baltimore, Md.: Johns Hopkins University Press, 2003.

- Torrid Zones: Maternity, Sexuality and Empire in Eighteenth-Century English Narratives. Baltimore: Johns Hopkins U P, 1995.

O'Quinn, Daniel. Staging Governance: Theatrical Imperialism in London, 1770-1800. Baltimore: Johns Hopkins University Press, 2005.

Prakash, Gyan. 'Can the 'Subaltern' Ride? A Reply to O’Hanlon and Washbrook.' Comparative Studies in Society and History 34.01 (1992): 168-184.

—. 'W riting Post-Orientalist Histories of the Third World: Perspectives from Indian Historiography.' Comparative Studies in Society and History 32.02 (1990): 383-408.

Rangarajan, Padma. Imperial Babel. Translation, Exoticism, and the Long Nineteenth Century. New York: Fordham University Press, 2014.

Rajan, Balachandra. Under Western Eyes: India from Milton to Macaulay. Durham, NC: Duke University Press, 1999.

Raman, Bhavani. Document Raj: Writing and Scribes in Early Colonial South India. University Of Chicago Press, 2012.

Said, Edward W. Orientalism. Harmondsworth: Penguin, 1978.

—. 'Orientalism Reconsidered.' Cultural Critique 1 (1985): 89. CrossRef. Web. 4 Oct. 2014.

Schürer, Norbert. 'Surveying the Eighteenth-Century Anglo-Indian Canon.' Literature Compass 7.7 (2010): 597-609.

Schwab, Raymond. La Renaissance Orientale. Paris: Payot, 1950.

Sharafuddin, Mohammad. Islam and Romantic Orientalism: Literary Encounters with the Orient. London: Tauris, 1994.

Stoler, Ann Laura. Along the Archival Grain. Princeton University Press, 2010. Print.

- Carnal Knowledge and Imperial Power: Race and the Intimate in Colonial Rule. University of California Press, 2002.

- Race and the Education of Desire: Foucault's History of Sexuality and the Colonial Order of Things. Duke University Press. 1995.

_ ' Rethinking Colonial Categories: European Communities and the Boundaries of Rule.' Comparative Studies in Society and History 31.01 (1989): 134-161.

Suleri, Sara. The Rhetoric of English India. Chicago: U of Chicago P, 1992.

Tavakoli-Targhi, Mohamad. Refashioning Iran: Orientalism, Occidentalism, and Historiography. Basingstoke; New York: Palgrave, 2001.

Teltscher, Kate. India Inscribed: European and British Writing on India, 1600-1800. Delhi: OUP, 1995.

Trautmann, Thomas R. Aryans and British India. Yoda Press, 2004.

- Languages and Nations the Dravidian Proof in Colonial Madras. Berkeley: University of California Press, 2006.

Viswanathan, Gauri. Masks of Conquest: Literary Study and British Rule in India. Columbia University Press, 1989.

Wagoner, Phillip B. 'Precolonial Intellectuals and the Production of Colonial Knowledge.' Comparative Studies in Society and History 45.04 (2003): 783-814. Cambridge Journals Online. Web. 6 Oct. 2014.

White, Daniel E. From Little London to Little Bengal: Religion, Print, and Modernity in Early British India, 1793-1835. Baltimore, Maryland: The Johns Hopkins University Press, 2013.

Wilson, Kathleen. A New Imperial History: Culture, Identity and Modernity in Britain and the Empire, 1660-1840. Cambridge University Press, 2004.

\section{Related Articles in Literature Compass}

Bhowmik, Urmi. 'Globalizing the Eighteenth Century.' Literature Compass 1.1 (2004).

Bolton, Carol. 'Romantic Literature and Colonialism.' Literature Compass 5.3 (2008): 541-553.

Das, Nandini. “"[A] Place Among the Hindu Poets”: Orientalism and the Poetry of Sir William Jones (1746-1794).' Literature Compass 3.6 (2006): 1235-1252.

Eaton, Natasha. "'Enchanted Traps?” The Historiography of Art and Colonialism in Eighteenth-Century India.' Literature Compass 9.1 (2012): 15-33.

Markley, Robert. 'China and the English Enlightenment: Literature, Aesthetics, and Commerce.' Literature Compass 11.8 (2014): 517-527.

Narain, Mona. 'Eighteenth-Century Indians' Travel Narratives and Cross-Cultural Encounters with the West.' Literature Compass 9.2 (2012): 151-165.

Rudd, Andrew. 'Romantic Period Writing and India.' Literature Compass 1.1 (2004).

Schürer, Norbert. 'Surveying the Eighteenth-Century Anglo-Indian Canon.' Literature Compass 7.7 (2010): 597-609. 
Taylor, Susan. 'Orientalism in the Romantic Era.' Literature Compass 1.1 (2004).

Ward, Adrienne. 'Eastern Others on Western Pages: Eighteenth-Century Literary Orientalism.' Literature Compass 1.1 (2004).

\section{Further Reading}

Baktir, Hasan. The Representation of the Ottoman Orient in Eighteenth-Century English Literature: Ottoman Society and Culture in Pseudo-Oriental Letters, Oriental Tales and Travel Literature. Stuttgart: Ibidem Verlag, 2010.

Caracciolo, Peter L. The Arabian Nights in English Literature: Studies in the Reception of the Thousand and One Nights into British Culture. Basingstoke: Macmillan, 1988.

Cohn, Bernard. Colonialism and Its Forms of Knowledge. The British in India. Princeton, NJ: Princeton University Press, 1996.

Conant, Martha Pike. The Oriental Tale in England in the Eighteenth Century. New York: Columbia UP, 1908.

Dalrymple, William. White Mughals. London: Harper Perennial, 2004.

Grenby, MO. 'Orientalism and Propaganda: The Oriental Tale and Popular Politics in Late-Eighteenth-Century Britain.' Eighteenth-Century Novel 2 (2002): 215-237.

Hoeveler, Diane Long and Jeffrey Cass. Interrogating Orientalism: Contextual Approaches and Pedagogical Practices. Columbus: Ohio State University Press, 2011.

Jasanoff, Maya. Edge of Empire. Conquest and Collecting in the East 1750-1850. London: Alfred A. Knopf, 2005.

Jokic, Olivera. 'Commanding Correspondence: History and 'Evidence of Experience' in the Letterbook of John Bruce, the East India Company Historiographer.' The Eighteenth Century: Theory and Interpretation 52.2 (2011): 109-136.

MacLean, Gerald M. Looking East: English Writing and the Ottoman Empire Before 1800. Basingstoke: Palgrave Macmillan, 2007.

McLeod, Bruce. The Geography of Empire in English Literature, 1580-1745. Cambridge: Cambridge University Press, 1999.

Ogborn, Miles. Global Lives. Britain and the World, 1550-1800. Cambridge: CUP, 2008.

Porter, Roy and George Sebastian Rousseau. Exoticism in the Enlightenment. Manchester: Manchester University Press, 1990.

Singh, Jyotsna. Colonial Narratives/Cultural Dialogues: Discoveries of India in the Language of Colonialism. London: Routledge, 1996.

Subrahmanyam, Sanjay. Three Ways to Be Alien: Travails and Encounters in the Early Modern World. Waltham, MA: Brandeis University Press, 2011. 